\title{
MODEL PEMBELAJARAN DARING PASCA PANDEMI COVID 19
}

\author{
Sy. Rohana \\ Sekolah Tinggi Agama Islam Negeri Teungku Dirundeng Meulaboh \\ Email: sy.rohana6@gmail.com
}

\begin{abstract}
Abstrak
Pesatnya teknologi informasi bisa menjawab permasalahan yang muncul pasca pandemi Covid- 19 terutama permasalahan proses pembelajaran. Teknologi informasi yang ikut andil dalam dunia pendidikan yang sekarang lagi buming adalah pembelajaran daring.Pembelajaran daring jelas berbeda dengan pembelajaran biasa, pembelajaran daring lebih mengedepankan kepada kemampuan anak didik dalam menerima dan mengolah informasi. Pembelajaran daring berfungsi sebagai penghubung antara guru dengan anak didiknya melalui jaringan internet yang dapat diakses kapan saja dan dimana saja. Media daring yang digunakan dalam proses pembelajaran bemacam-macam diantaranya; WhatsApp, Google Meet, Zoom, Classroom dan bahkan ada juga e- learning. Tetapi diantara bebrapa media tadi yang paling simple digunakan adalah WhatsApp mudah untuk akses di setiap jenjang pendidikan. Pembelajaran daring saat ini menjadi media yang efektif untuk proses pembelajaran di semua jenjang. Untuk efektifnya dan optimalnya proses pembelajaran daring, ada beberapa model pembelajaran yang ditawarkan oleh para ahli di masa pandemic Covid-19 diantara; Model Daring, Model Luring, Model e-learning Daring, Project Based Learning, dan Blended Learning.
\end{abstract}

Kata kunci: Pembelajaran daring, covid-19, teknologi informasi

\begin{abstract}
The sophisticated information and technology (IT) development can be the answer for various problems post the covid-19 pandemic, particularly the teaching and learning challenges. The role of IT that is booming nowadays is the online learning. Online learning is obviously different from regular learning. In this mode of learning, the students are required to have the ability to receive and process information. It serves as media that connect teacher and students who are being remote from one another at anytime and anyplace. There are various media utilized to perform online learning such as WhatsApp, Google Meet, Zoom, Google Classroom, and other e-learning platforms. Among all these media, though, WhatsApp apparently appointed as the simplest and easiest media to access in all level of education. Online learning at current is the effective media to carry on the teaching and learning process in all level of education. For the effectiveness of online teaching and learning process during the covid-19 pandemic, there have been a number of learning models suggested by the expert such as remote learning, face to face learning, $e$ learning, project-based learning, and Blended Learning.
\end{abstract}

Keywords: online learning, covid-19, information technology 


\section{A. PENDAhULUAN}

Kita ketahui bahwa didunia pendidikan belajar tidak hanya di sekolah saja, tapi di tiga pusat atau dengan istilah tri pusat pendidikan. Ketiga pusat pendidikan ini si anak akan mendapat pengajaran baik secara langsung maupun tidak langsung, dalam kehidupan keluarga, sekolah dan masyarakat. Secara informal, formal dan non formal harus terintegrasi, sehingga proses yang didapatkan oleh anak didik sinergi ketiga-tiganya. Seseorang baru dikatakan belajar bila pada dirinya terjadi aktivitas yang mengakibatkan terjadinya perubahan tingkah laku, untuk terjadinya perubahan tingkah laku maka dalam proses pembelajaran setiap anak didik harus terlibat secara aktif guna mencapai tujuan dari sebuah pembelajaran.

Disini memerlukan bantuan dari orang lain yakni guru, untuk memberi dorongan dan motivasi dalam proses pembelajaran agar anak didik terlibat secara totalitas. Maka guru harus menguasai baik materi maupun strategi dalam pembelajaran. Menurut Slameto (2003: 92-94) guru dalam mengajar harus efektif baik untuk dirinya maupun untuk pembelajaran. Untuk melaksanakan pembelajaran yang efektif diperlukan syarat-syarat berikut: Belajar secara aktif, baik mental maupun fisik; Guru harus mempergunakan banyak metode pada waktu mengajar; Motivasi; Kurikulum yang baik dan seimbang; Guru perlu mempertimbangkan perbedaan individual; Guru akan mengajar efektif bila selalu membuat perencanaan sebelum mengajar; Pengaruh guru yang sugestif perlu diberikan pula kepada siswa; Seorang guru harus memiliki keberanian menghadapi siswa-siswanya; Guru harus mampu menciptakan suasana demokratis di sekolah; Guru perlu memberikan masalah-masalah yang merangsang untuk berfikir; Semua pelajaran yang diberikan pada siswa perlu diintegrasikan.

Pembelajaran adalah upaya untuk mengkondisikan anak didik supaya terjadi proses pembelajaran, dengan cara memb erikan stimulus dengan memfasitasi anak didik dengan berbagai sumber model pembelajaran salah satunya di masa pandemic Covid-19 dengan cara daring (online). Guru harus mampu mendesain model pembelajaran yang sesuai dengan materi dan karakter anak didik. Penggunaan aplikasi pada pembelajaran daring sanagat membantu guru dalam proses pembelajaran. Guru harus bisa atau terbiasa mengajar dengan mamanfaatkan media daring yang didesain untuk mudah di akses dengan efektif sehingga mudah dipahami oleh anak didik. Guru dituntut mampu merancang dan mendesaiin pembelajaran daring yang ringan dan efektif, dengan memanfaatkan parangkat atau media daring yang tepat dan sesuai dengan materi yang diajarkan.

Yang paling sederhana dapat dilakukan guru salah satunya memanfaatkan WhatsApp. Aplikasi WhatsApp mudah untuk digunakan bagi pembelajaran daring pemula, karena sangat simpel dan mudah di akses oleh anak didik. Sedangkan bagi yang mengajar online banyak aplikasi pembelajaran daring. Mengingat keterbatasan infrastruktur perangkat seperti jaringan sangat efektif guru menggunakan Zoom Meeting, e- learning dan lain-lain.

Keberhasilan guru dalam melakukan pembelajaran daring pada situasi pandemic Covid19 ini adalah kemampuan guru dalam berinovasi merancang model dan metode pembelajaran. Diharapkan pembelajaran daring merupakan sebuah solusi yang efektif dalam pembelajaran di rumah guna memutus mata rantai penyebaran Covid- 19, physical distancing (menjaga jarak aman) juga menjadi pertimbangan dipilihnya pembelajaran daring. Di sini membutuhkan Kerjasama yang baik anatara guru, anak didik, orang tua, sekolah dan masyarakat menjadi faktor penentu agar pembelajaran daring lebih efektif. Semoga pandemi Covid-19 cepat berlalu seiring 
dengan new normal yang telah diberlakukan oleh perintah, sehingga proses pembelajaran bisa terlaksana.

\section{B. HASIL DAN PEMBAHASAN}

\section{Model Pembelajaran}

Model pembelajaran untuk membelajarkan anak didik sesuai dengan cara belajar mereka sehingga tujuan pembelajaran dapat dicapai dengan baik. Karena itu dalam memilih model pembelajaran yang tepat haruslah memperhatikan kondisi anak didik, sifat dari materi atau bahan ajar, fasilitas, media yang tersedia dan kondisi guru sendiri.

Model pembelajaran adalah keseluruhan rangkaian kegiatan penyajian materi pembelajaran yang meliputi segala aspek, baik sebelum, dan sedang, maupun sesudah terjadinya proses pembelajaran yang dilakukan oleh guru, dengan segala fasilitas yang terkait dengan pembelajaran. Fasilitas tersebut baik digunakan secara langsung atau tidak langsung dalam proses pembelajaran.

Menurut Jihat dan Harris (2012) model pembelajaran dapat diartikan sebagai suatu rencana atau pola yang digunakan dalam menyusun kurikulum, mengatur, materi peserta didik, dan memberi petunjuk kepada pengajar di kelas dalam setting pengajaran atau setting lainnya. Fungsi Model Pembelajaran adalah sebagai pedoman bagi pengajar dan para guru dalam melaksanakan pembelajaran. Hal ini menunjukkan bahwa setiap model yang akan digunakan dalam pembelajaran menentukan perangkat yang dipakai dalam pembelajaran tersebut. Selain itu, model pembelajaran juga berfungsi sebagai pedoman bagi para perancang pembelajaran dan para pengajar dalam merencanakan dan melaksanakan aktivitas belajar mengajar sehingga tujuan pembelajaran dapat tercapai. Istilah model Pembelajaran mempunyai makna yang lebih luas daripada strategi, metode, atau prosedur. Menurut Kadir dan Nur Model Pembelajaran Inovatif dalam Kurikulum 2013 bahwa Model pembelajaran mempunyai empat ciri khusus yang tidak dimiliki oleh strategi, metode, atau prosedur. Ciri-ciri tersebut antara lain:

a. Rasional teoritik yang logis, disusun oleh para pencipta atau pengembangnya;

b. Landasan pemikiran tentang apa dan bagaimana siswa belajar (tujuan pembelajaran yang akan dicapai);

c. Tingkah laku mengajar yang diperlukan agar model tersebut dapat dilaksanakan dengan berhasil;

d. Lingkungan belajar yang diperlukan agar tujuan pembelajaran itu dapat tercapai.

Pembelajaran daring pasca munculnya wabah Covid 19 di belahan bumi, dengan munculnya wabah covid 19 maka sistem pendidikan mulai mencari suatu kreatifitas,dan inovasi untuk keberlangsungan proses belajar mengajar.

\section{Dasar Hukum Pelaksanaan Pembelajaran Daring}

Ada beberapa dasar hukum pelaksanaan Pembelajaran secara daring di masa pandemi, antara lain sebagai berikut:

a. Surat Edaran Nomor 36962/MPK.A/HK/2020 agar seluruh kegiatan belajar mengajar baik di sekolah maupun kampus perguruan tinggi menggunakan metoda daring (dalam jaringan) alias online sebagai upaya pencegahan terhadap perkembangan dan penyebaran Coronavirus disease (Covid-19). 
b. Keputusan Bersama Menteri Pendidikan dan Kebudayaan, Menteri Agama, Menteri Kesehatan, dan Menteri Dalam Negeri RI Nomor 01/KB/2020/ Nomor 516 tahun 2020 Nomor HK.03.01/Menkes/363/2020 Nomor 440-882 Tahun 2020 tentang Panduan Penyelenggaraan Panduan Penyelenggaraan Pembelajaran pada Tahun Ajaran 2020/2021 dan Tahun Akademik 2020/2021 di Masa Pandemi Corona Virus Disease 2019 (Covid -19).

c. Keputusan Bersama Menteri Pendidikan dan Kebudayaan, Menteri Agama, Menteri Kesehatan, dan Menteri Dalam Negeri RI Nomor 03/KB/2020 Nomor 612 Tahun 2020 Nomor HK.01.08/Menkes/502/2020 Nomor 119/4536/SJ Tentang Perubahan atas Keputusan Bersama Menteri Pendidikan dan Kebudayaan, Menteri Agama, Menteri Kesehatan, dan Menteri Dalam Negeri RI Nomor 01/KB/2020, Nomor 516 Tahun 2020., Nomor HK.03.01/Menkes/363/2020, Nomor 440-882 Tahun 2020 Tentang Panduan Penyelenggaraan Pembelajaran pada Tahun Ajaran 2020/2021 dan Tahun Akademik 2020/2021 di Mada Pandemi Corona Virus Disease 2019 (Covid19).

d. Surat Edaran Menteri Agama RI Nomor: B-1673.1/DJ.1/08/2020 Tentang Panduan Penyelenggaran Pembelajaran pada Tahun Ajaran 2020/2021 dan Tahun Akademik 2020/2021 Bagi Satuan Pendidikan Madrasah, Pesantren, Pendidikan Keagamaan Islam, dan Perguruan Tinggi Keagamaan Islam di Masa Pandemi Corona Virus Disease 2019 (Covid-19).

Dasar pertama yaitu dengan diterbitnya Surat Edaran No; 4 Tahun 2020 dari Menteri Pendidikan dan Kebudayaan mulai 16 Maret 2020 menganjurkan seluruh kegiatan di institusi pendidikan harus jaga jarak dan seluruh penyampaian materi akan disampaikan di rumah masing-masing. Setiap Lembaga Pendidikan dituntut untuk memberikan inovasi terbarukan untuk membentuk proses pembelajaran pasca Covid 19 agar proses pembelajaran tidak terhenti. Tidak semua Lembaga Pendidikan paham tentang inovasi terbarukan yang harus dilaksanakan dalam melakukan proses pembelajaran pasca Pandemi Covid 19, kebanyakan masih belum bisa menyesuaikan, apalagi terkendala dengan sarana dan prasarana. Ada beberapa model pembelajaran terbarukan yang cocok dengan peserta didik pasca Pandemi Covid 19.

Salah satunya kegiatan belajar dirumah yang mengganti sama seperti belajar di ruang kelas sekolah. Praktisi pembelajaran dari Shinkejuku Keiko Toyoizumi mengatakan, guru perlu memberikan motivasi pada anak didik untuk tetap semangat melakukan pembelajaran dalam jaringan (daring) di rumah selama merebak pandemic virus Covid 19. Disini guru sangat perlu memberikan motivasi kepada anak didiknya, agar ia termotivasi dan bersemangat dan terus melakuka pembelajaran daring di rumah, guru harus memberikan dukungan secara mendalam serta mendorong motivasi peserta didik, kebiasaan belajar, mengatur waktu, dan kemampuan untuk berfikir secara mandiri. Karena melalui proses pembelajaran daring anak didik lebih mandiri, sangat berbeda dengan pembelajaran tatap muka kebiasaan anak didik bila individu tidak bisa, maka bisa saja diselesaikan melalui kelompok. Proses pembelajaran daring anak didik bisa bertanya langsung pada gurunya mengenai hal yang dia tidak mengerti, di dengarkan penyampaian dari anak didik dan fasilitasi dengan sebaik-baiknya.

Pembelajaran daring dilaksanakan tanpa paksaan terhadap anak didik, tujuan dari pembelajaran harus ditentukan secara bersama, karena ada guru memberikan tugas banyak 
kepada anak didiknya hal ini membuat anak didik merasa terbebani. Pelaksanaan pembelajaran dirumah aman bagi anak didik pasca Pandemi Covid 19. Ahli Psikolog dari Universitas Indonesia (UI) Rose Mini Agoes Salim mengingatkan setiap orang tua harus bijak dalam memberikan gawai pada anak selama mereka menjalani proses belajar di rumah saat pandemi COVID-19. "Sebaiknya tidak diberi gawai, tapi jika memang tidak diberi gawai mereka juga jangan disuruh hanya diam saja," (sumber : rodajaman.blogspot.com/WA Group Fordorum/ Mendikbud.id/)

\section{Efektiftivitas Pelaksanaan Pembelajaran Daring Pasca Covid 19}

Sampai saat ini Covid 19 masih menjadi pembicaraan yang hangat atau masih menjadi trending topik di seluruh dunia. Covid 19 adalah sejenis virus yang menular pertama kali di jangkit di kota Wuhan Cina pada akhir desember 2019. Virus ini sangat cepat menular dan telah menyebar ke berbagai negara termasuk kita Indonesia, hanya dalam waktu beberapa bulan saja, sehingga WHO pada tanggal 11 Maret 2020 menetapkan wabah ini sebagai pandemi yang mengglobal. Banyak negara menetapkan kebijakan untuk memberlakukan lockdown dalam rangka mencegah penyebaran covid 19 ini. Di Indonesia diberlakukan kebijakan Pembatasan Sosial Berskala Besar (PSBB) untuk menekan penyebaran covid 19 ini, maka semua kegiatan yang dilakukan di luar rumah di hentikan sampai pandemi covid 19 ini berkurang.

Banyak negara mengambil kebijakan dengan menerapkan metode belajar sistem daring (dalam jaringan) atau online, dengan meliburkan anak didik. Kebijakan ini mulai efektif diberlakukan di beberapa wilayah provinsi di Indonesia pada hari senin 16 Maret 2020 yang diikuti oleh provinsi-provinsi lainnya. Ada sekolah-sekolah yang terisolir tidak siap dengan sistem pembelajaran daring, karena membutuhkan media pembelajaran seperti handphone, laptop atau komputer. Pembelajaran daring (dalam jaringan) adalah sistem pembelajaran tanta tatap muka secara langsung antara guru dan siswa, tetapi dilakukan melalui online yang menggunakan jaringan internet. Guru harus memastikan kegiatan pembelajaran harus tetap berlangsung meskipun anak didik dirumah, dengan demikian seorang guru harus mendesaian media dan model pembelajaran sebagai inovasi dengan memenfaatkan media daring (dalam jaringan) online.

Sesuai dengan edaran Menteri pendidikan dan Kebudayaan RI nomor 4 tahun 2020 terkait dengan Pelaksanaan Kebijakan Pendidikan dalam masa darurat penyebaran Corona Virus Disease (COVID-19), bahwa sistem pembelajaran dilaksanakan melalui perangkat personal computer (PC) atau laptop yang terhubung dengan koneksi jaringan internet. Guru dapat melaksanakan pembelajaran bersama diwaktu yang sama menggunakan grup di media sosial seperti; WhatsApp (WA), telegram, instagram, aplikasi Zoom, meet, dan media lainya sebagai media pembelajaran. Guru dapat memastikan anak didik mengikuti pembelajaran dalam waktu yang bersamaan, walaupun tempatnya berbeda.

Disetiap sektor merasa berdampak dari Covid-19, salah satunya dunia pendidikan, bila kita lihat kejadian disekitar yang sedang terjadi baik anak didik maupun orang tua yang tidak memiliki handphone untuk proses pembelajaran daring akan merasa sedih, disini pihak sekolah ikut mencari solusi untuk berjalannya proses pembelajaran. Bagi anak didik yang tidak mempunyai handphone melakukan pembelajaran secara kelompok, sehingga mereka bisa melakukan aktivitas secara bersama-sama. Mulai belajar dengan menggunaka vidiocall yang dihubungkan ke guru mata pelajaran, layaknya sebuah proses pembelajaran tatap muka. Guru 
memberikan penjelasan terkait dengan materi yang diajarkan dan memberikan pertanyaanpertanyaan dan mengabsen anak didik melalui VoiceNote yang tersidia di WhatsApp.

Secara umum permasalahan yang terjadi bukan hanya di media pembelajaran, aka tetapi di pada ketersediaan kuota yang membutuhkan biaya cukup tinggi. Bukan itu saja ada anak didik yang tinggal sulit untuk mengakses internet, dan yang terjangkau internet banyak diberbagai media sosial menceritakan pengalaman orang tua anak didik dalam mendampingi anaknya belajar ada yang marah-marah mungkin disini orang tua sadar bahwa mendidik anak itu tidak mudah memerlukan kesabaran dan tidak dengan gampang menyalahkan guru bila anaknya mendapat nilai tidak sesuai dengan yang diharapkan.

Disadari juga ketidaksiapan guru dan siswa dalam pembelajaran daring, kerena ini secara cepat perpindahan system dari tatap muka ke daring tanpa kesiapan yang optimal. Semua ini harus dilaksanakan agar proses pembelajaran dapat berjalan lanca siswa aktif mengikuti walaupun dalam kondisi Covid-19.

Untuk tahun ajaran 2020/2021 pemerintah sudah mengeluarkan Salinan Keputusan Menteri Keuangan Republik Indonesia Nomor: 394/KMK.02/2020 Tentang Biaya Paket Data Komunikasi Tahun Anggaran 2020 Menteri Keuangan Republik Indonesia. Dalam Ketetapan pada point ketiga "Kepada mahasiswa yang mengikuti kegiatan belajar mengajar secara daring (online) dan masyarakat yang terlibat dalam kegiatan secara daring (online) yang bersifat insidentil dapat diberikan biaya paket data sesuai kebutuhan paling tinggi sebesar Rp 150.000,per orang/ bulan". Ini merupakan salah satu solusi secara finansial, apakah Salinan Putusan Menteri Keuangan ini juga diberlakukan untuk para siswa.

Kemudian menurut Agus Mustakim Instruktur Nasional Kurikulum PAI dan Budi Pekerti Kemenag RI dalam Webinar Internasional di STAIN Teungku Dirundeng Meulaboh tanggal 19 Agustus 2020. "Extraordinary Teaching Dalam Pembelajaran Daring". Ada tiga tantangan pendidik di masa pandemi Covid-19 dalam melaksanakan tugas dan tanggung jawab pendidik dalam pembelajaran:

a. Pembelajaran Abad ke 21

1) Pondasi dasar berupa pengetahuan inti, literasi digital dan informasi, serta pengetahuan interdisipliner.

2) Kemampuan humanistik yang meliputi ketrampilan hidup, cerdas emasional, dan kompetensi kultural.

3) Ketrampilan berpikir kritis, kreatif, kalaboratif, dan komunikatif.

b. Pembelajaran Jarak Jauh

1) Bukan sekedar membagi vidio dan tugas

2) Pembelajaran jarak jauh didesain menggunakan model dan pendekatan pembelajaran abad ke 21 (PBL, PJBL, Inquiry, dan lain-lain)

3) Tahapan normatif pembelajaran; pendahuluan, inti, penutup tetap harus ada.

4) Pembelajaran jarak jauh, pembelajaran biasa yang diterapkan dengan cara yang berbeda .

c. Apatisme Terhadap Pembelajaran Jarak Jauh

1) Pembelajaran jarak jauh mahal?

2) Pembelajaran jarak jauh tidak efektif?

3) Tidak semua orang tua peduli ? 
4) Susah sinyal dan tidak punya HP.

Ketiga tantangan tersebut diatas yang menjadi permasalahan dan harus di hadapi guru, disini guru benar- benar harus peposisikan dirinya sebagai guru yang profesional sehingga bisa mengahadapi dan menjawab semua tantangan dalam proses pembelajaran dengan anak didiknya, walau dalam masa pandemi Covid-19. Guru itu harus memiliki kompetensi abad 21, maka untuk mewujudkan anak didik yang memiliki ketrampilan abad 21 seorang guru harus mampu memahami dan memiliki kampotensi tersebut. Salah satu hal terpenting dalam kompetensi abad 21; karakter yang bersifat akhlak (jujur. Amanah,, sopan,santun dan lain-lain) dan karakter kinerja (kerja keras, tanggung jawab, disiplin, gigih dan lain-lain).

Disamping itu guru pada masa covid-19 harus peka terhadap empat kompetensi yang harus di intepretasikan dalam proses pembelajaran seperti; kompetensi sosial disini guru harus ada keperpihakan dan kepedulian kepada anak didik;kompetensi kepribadian disini guru dituntut dengan dedikasi yang tinggi baik tenaga, pikiran dan waktu demi keberlangsungan atau tercapainya proses pendidikan dengan baik dan selalu memberikan motivasi kepada anak didiknya; kompetensi pedagogik guru selalu upgrade kompetensi artinya guru dituntut untuk meningkatkan kualitas dalam mempercepat transformasi pendidikan, dan harus mampu mengelolala informasi dan pengetahuan, seberapa mampu guru mengembangkan pola pikir sehingga memiliki kemampuan mencerna dan menolah informasi. Ada tiga indikator seorang guru baru bisa dikatakan mampu mengembangkan daya pikir, antara lain; dengan melihat prilaku anak didik, kemampuan anak didik dalam belajar melihat dari hasil ujian nasional, serta melihat kebiasaan anak didik dalam menghabiskan waktu apakah anak didik melakukan sesuatu yang positif, atau sebaliknya; kompetensi professional kemampuan seorang guru dalam menguasai materi pembelajaran secara luas dan mendalam yang meliputi konsep, struktur, dan metode, keilmuan/teknologi untuk mencapai tujuan dari pembelajaran.

\section{Model atau Media yang digunakan Dosen STAIN Teungku Dirundeng Meulaboh.}

Penulis membuat survey tentang efektifitas pembelajaran daring pasca Covid-19 di perguruan tinggi yaitu pada mahasiswa STAIN Teungku Dirundeng Meulaboh. Walaupun tulisan ini menggambarkan proses pelaksanaan pembelajaran daring di semua jenjang mulai dari SD s/d PT.

Untuk memperoleh hasil dari survey tentang efektifitas pembelajaran daring, dengan menggunakan google form. Pertanyaan survey dalam bentuk response tertutup (multiple choices) dan Sebagian kecil berupa pertanyaan terbuka. Informasi survey disebar luaskan melalui WA ke mahasiswa STAIN Teungku Dirundeng Meulaboh. 


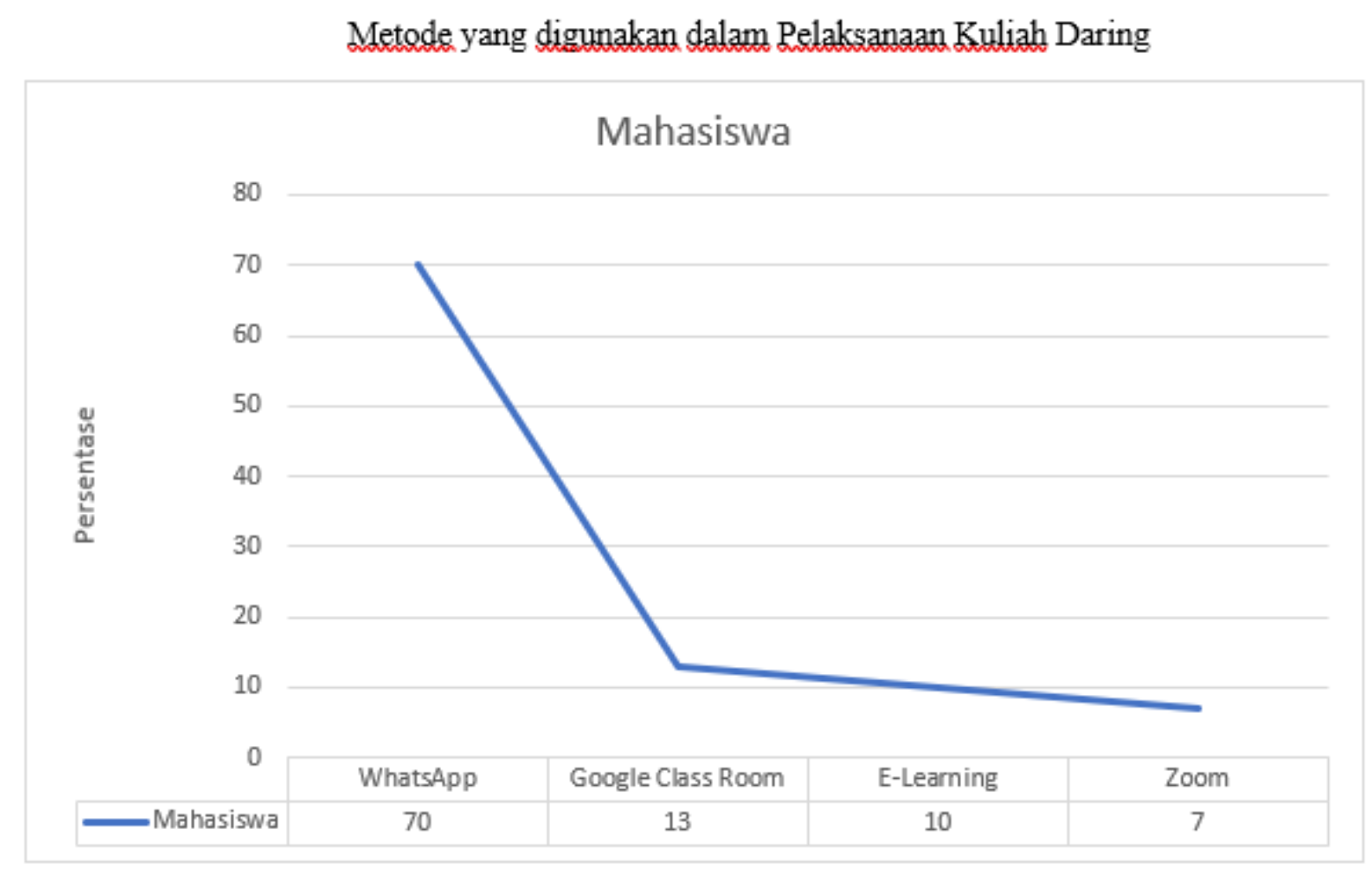

Berdasarkan Surat Edaran Nomor 36962/MPK.A/HK/2020 agar seluruh kegiatan belajar mengajar baik di sekolah maupun kampus perguruan tinggi menggunakan metode daring (dalam jaringan) alias online sebagai upaya pencegahan terhadap perkembangan dan penyebaran Coronavirus disease (Covid-19). Pada semester genap 2019-2020 pelaksanaan kuliah daring mulai maret 2020. Dalam hal ini setelah penulis mengadakan survey dengan menggunakan Google Form, maka jawaban mahasiswa terhadap pertanyaan tersebut bervariasi terhadap model dan media yang digunakan Dosen STAIN Teungku Dirundeng Meulaboh.

Yang menjawab $70 \%$ terhadap penggunaan media WhatsApp, memudahkan mahasiswa dalam proses pembelajaran, karena mahasiswa banyak medomisili di luar kota Meulaboh, dan mengingat jaringan kalau berdomisili di pelosok. Terhadap jawaban Google Class Room 13 \%, E. Learning $10 \%$, dan Zoom $7 \%$, secara Akademik bagi dosen lebih memudahkan, karena semua data mahasiswa ada kontennya seperti di Google Class Room ada konten Forum, Tugas, Anggota, dan Nilai.

Menuzut anda sojauh mana efektifltas pembelalaran daringoascecovid - 19 ?

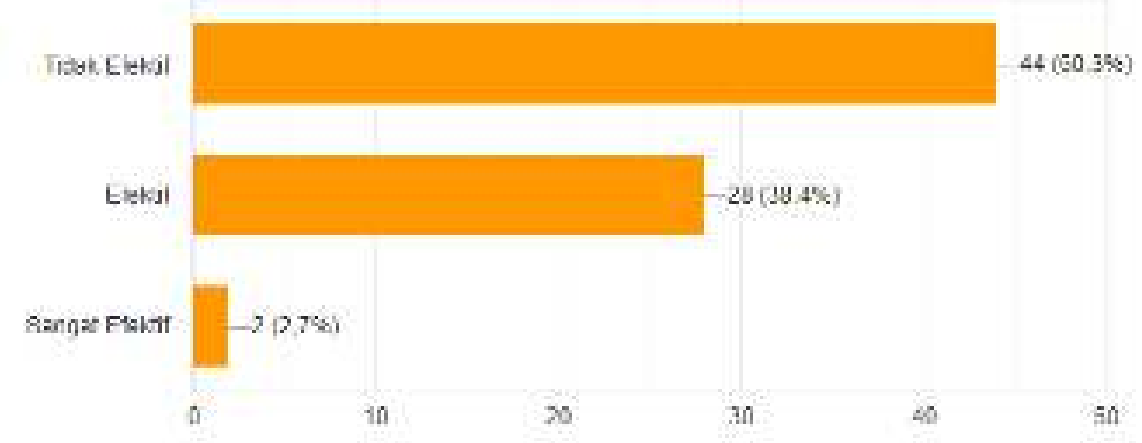


Ketika kita tanya kepada mahasiswa tentang efektivitas pembelajaran daring, 60,3\% menjawab tidak efektif, hal ini menunjukkan mahasiswa lebih memilih proses belajar mengajar dengan model luring, karena berkomunikasi secara langsung lebih efektif.

\section{Menurut anda apakah materi yang disampaikan oleh dosen anda melalui pembelajaran} daring dapat anda pahami?

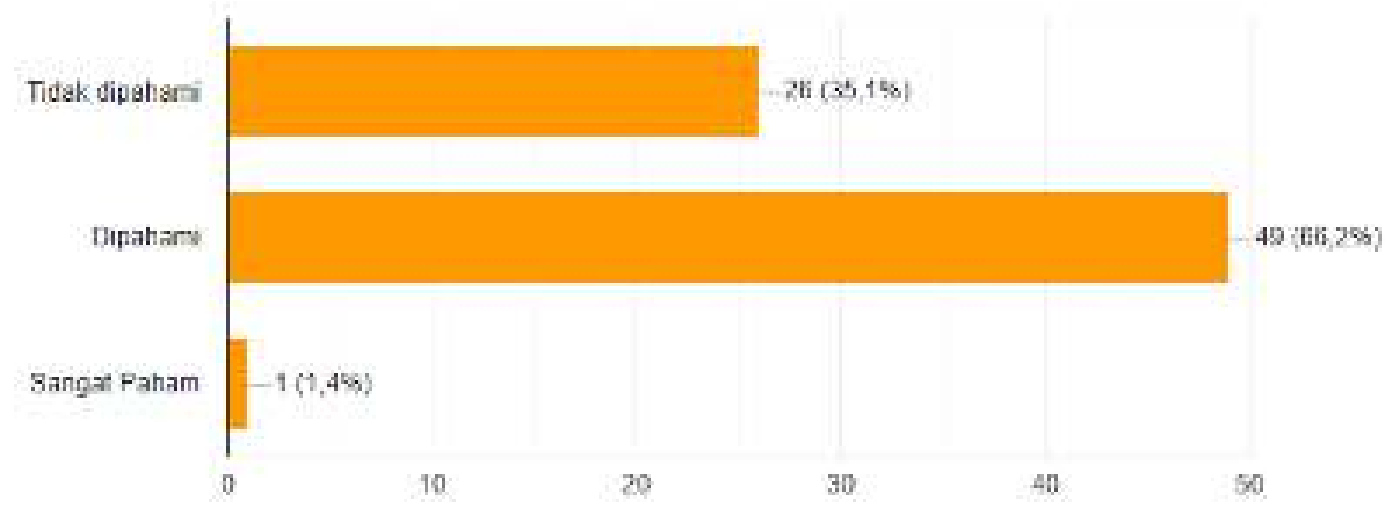

Kemudian ketika kita tanya kepada mahasiswa tentang pemahaman dari meteri pembelajaran melalui daring, 66,2 \% menjawab dapat dipahami dengan baik. Ini menunjukkan bahwa proses pembelajaran daring ada kemajuan atau keberhasilan, mengingat waktu yang sangat singkat dan mendadak mempersiapkan segala sesuatunya menyangkut pembelajaran daring.

Selama pelaksanaan kuliah daring seberapa baik dosen dalam menyampaikan materi kuliah daring?

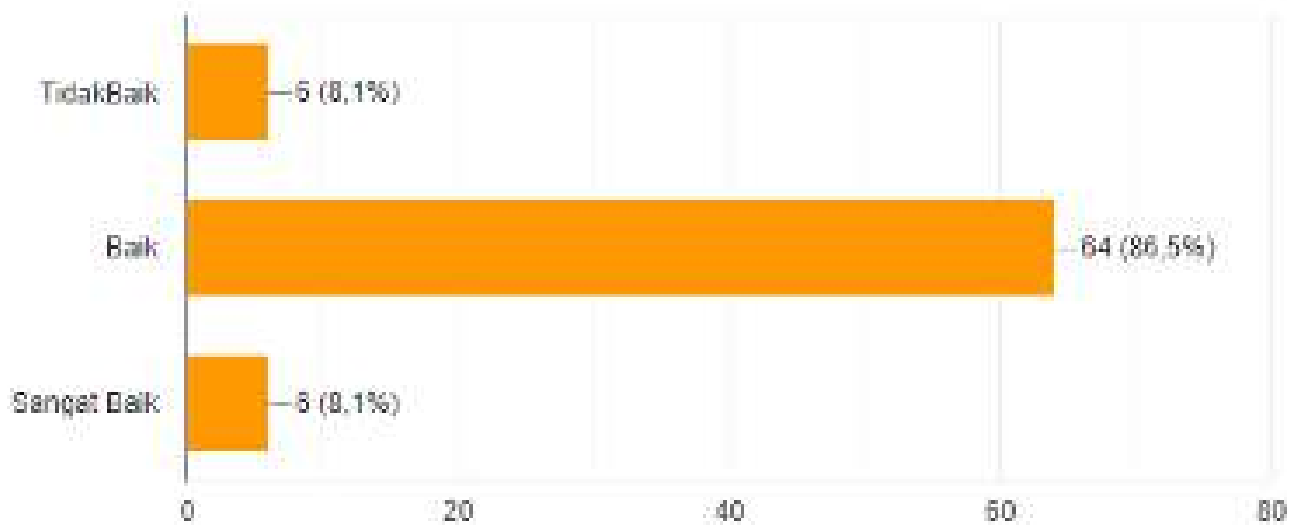

Selanjutnya respon dari mahasiswa terhadap pertanyaan seberapa baik dosen dalam menyampaikan materi kuliah dengan proses daring, 86,5 \% mahasiswa menjawab baik hingga sangat baik. 
Sclama pelaksanaan kuliah daring bagaimara kualitas materikulah yang diberikan dosen anda?

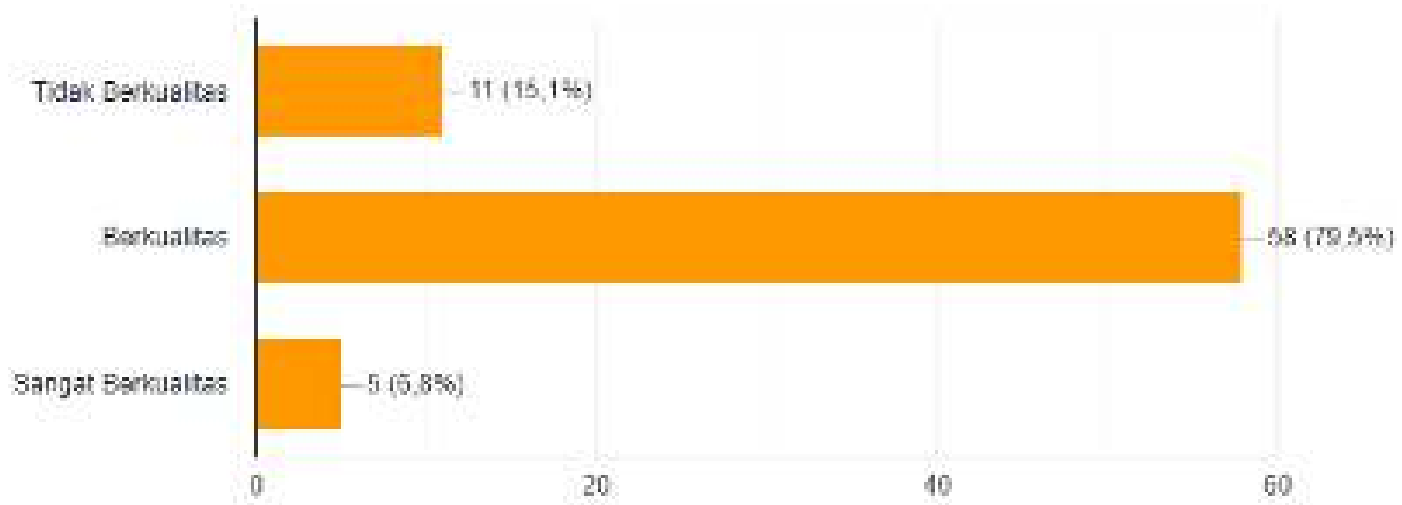

Kemudian terhadap pertanyaan kualitas penyajian materi kuliah daring, 79,5 \% jawabannya berkualitas. Karena kualitas dosen dalam menguasai teknologi tidak diragukan lagi, sesuai dengan tuntutan di era 4.0.

\section{Bagaimana tanggapan anda sebagai mahesiswa jka perkuliahan kembali dilakukan secara} daring / online?

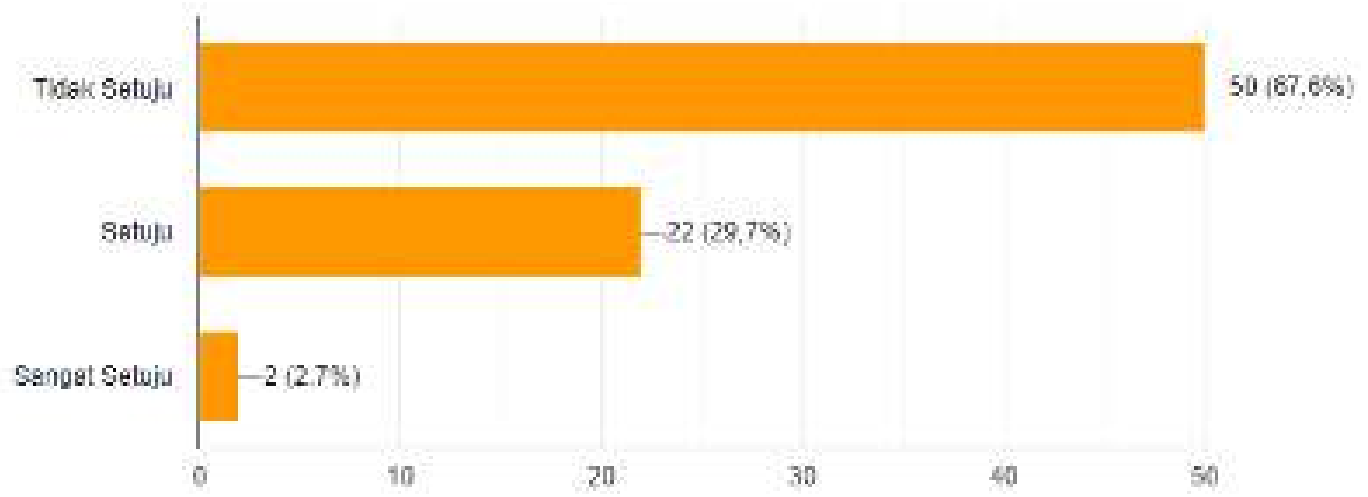

Kita ajukan pertanyaan kepada mahasiswa tentang pelaksanaan kuliah melalui daring kembali dilaksanakan, 67,6\% mengatakan tidak setuju.

Dari hasil survey diatas bahwa pembelajaran daring di tengah pandemi Covid- 19 tidak efektif dibandingkan pembelajaran tatap muka. Pembelajaran dengan model daring ini ada plus minusnya, walau pada kenyataannya peran dari guru/dosen itu tak tergantikan dengan media teknologi. Guru/dosen itu lebih bahagia berinteraksi langsung dengan anak didiknya, dan sebaliknya anak didik juga senang bila ia bertatap muka langsung dengan gurunya.

\section{Model Pembelajaran yang Efektif di masa Pandemi Covid-19}

Proses pembelajaran untuk anak didik yang sesuai dengan cara dan gaya belajar meraka untuk mencapai tujuan dari proses pembelajaran secara optimal ada berbagai model pembelajaran yang ditawarkan oleh para ahli pendidikan pasca pandemi Covid- 19. Guru dalam 
memilih model pembelajaran juga harus pemperhatikan kondisi anak didik, sifat, materi ajar, fasilitas, media yang tersedia dan kondisi guru itu sendiri.

Ada beberapa model pembelajaran untuk dipilih dan dijadikan alternatif semoga cocok untuk situasi dan kondisi sekarang pasca pandemi Covid-19. Walaupun demikian guru harus melakukan penyesuaian model pembelajaran agar tercapai tujuan dari materi pembelajaran yang akan diajar kepada anak didiknya.

a. Model Daring

Pasca pandemi Covid - 19 model pembelajaran daring bisa dijadikan salah satu model pembelajaran yang efektif untuk mengatasi persoalan pembelajaran. Diberitakan dari Kumparan, bahwa Kemendikbud mengungkapkan metode daringa bisa mengatasi permasalahan yang terjadi selama pandemi Covid- 19 ini berlangsung.

Model pembelajaran daring ini membuat anak didik untuk bisa memanfaatkan fasilitas yang ada di rumah dengan baik. Seperti membuat konten dengan memanfaatkan barang-barang disekitar rumah maupun mengerjakan seluruh kegiatan belajar melalui sistem online. Model pembelajaran daring ini sangatlah tepat diterapkan bagi anak didik yang berada pada kawasan zona merah. Dengan menggunakan model full daring, sistem pembelajaran yang disampaikan akan tetap berlangsung dan seluruh anak didik tetap berada di rumahnya masing-masing dalam suasana aman. Dampak dari kemajuan teknologi terhadap perkembangan pendidikan, maka para guru memanfaatkannya untuk mempermudah proses pembelajaran serta meningkatkan kualitas pendidikan pasca pendemi Covid - 19 .

b. Model Luring

Luring yang dimaksudkan pada model pembelajaran yang dilakukan di luar jaringan, artinya pembelajaran dilakukan dengan cara tatap muka, yang harus memperhatikan zonasi dan protokol kesehatan yang berlaku. Model pembelajaran ini cocok untuk anak didik yang berada di wilayah zona kuning atau hijau dengan mengutamakan protokol ketat new normal.

Model pembelajaran luring ini anak didik akan mengikuti pembelajaran secara bergiliran (shift model) untuk menghindari kerumunan. Dikutip dari Kumparan, model pembelajaran ini disarankan oleh Kemendikbud untuk memenuhi penyederhanaan kurikulum selama darurat pandemi Covid- 19 ini. Model pembelajaran ini dirancang untuk menyiasati penyampaian kurikulum agar tidak kesulitan saat disampaikan kepada anak didik. Pembelajaran luring ini sangat cocok dan baik bagi anak didik yang kurang sarana dan prasarana untuk mendukung sistem pembelajaran daring.

c. E- Learning /Daring

Salah satu Universitas yaitu Universitas Terbuka (UT) yang menerapkan model pembelajaran e-pearning. Yang menjadi faktor utama adalah dalam distance learning yang selama ini dianggap masalah karena tidak terjadinya interaksi antara guru dengan anak didik artinya tidak terjadi proses pembelajaran secara langsung. Dengan teknologi salah satunya media internet sangat memungkinkan untuk melalkuakn interksi antara guru dengan anak didiknya, baik dalam bentuk real time (waktu nyata) atau non real time (tidak nyata). Dalam model real time dapat dilaksanakan dengan model class room, vidio, audio dan Zoom meting, Google Meet, dan lain-lain. Selanjutnya yang tidak real time bisa dilaksanakan atau dilakukan dengan mailing list, diskusi grup, dan buletin board. Dengan demikian interaksi antara guru dengan anak didik di kelas mungkin akan tergantikan walaupun tidak sepenuhnya. 
E- Learning adalah pembelajarang yang menggunakan rangkaian elektronik (LAN-WAN, atau internet) untuk menyampaikan materi pembelajaran dengan menggunakan media internet atau media jaringan computer lainnya. Sebagai salah satu solusi untuk dapat meningkatkan pengetahuan dan ketrampilan. Media belajar dengan menggunakan model e-learning akan mempermudah interaksi antara anak didik dengan guru, materi pelajaran dan dengan sesama anak didik. Anak didik dapat saling berbagi informasi dan dapat mengakses materi pelajran setiap saat secara berulang-ulang, dengan demikian anak didik dapat menguasai materi pelajaran. Dalam pembelajaran model e-learning yang mengambil peran guru adalah computer dan panduan-panduan elektronik yang dirancang oleh contents writer, designer e- learning.

Menurut Setiawan (2020); E-learning adalah suatu sistem pembelajaran dengan menggunakan sarana, yang dilaksanakan tanpa harus bertatap muka dengan secara langsung antara guru dengan anak didik .

Menurut Koswara (2006:377) kemampuan baru yang diperlukan guru atau dosen untuk $e$ learning antara lain:

1) Mengerti tentang e-learning

2) Mengidentifikasi karakteristik anak didik

3) Mendesain dan mengembangkan materi pelajaran atau materi kuliah yang interaktif sesuai dengan perkembangan teknologi baru

4) Mengadaptasi strategi pembelajaran untuk menyampaikan materi secara elektronik

5) Mengorganisir materi dalam format yang mudah untuk dipelajari

6) Melakukan training dan praktik secata elektronik

7) Terlibat dalam perencanaan, pengembangan, dan pengembilan keputusan

8) Mengevaluasi keberhasilan pembelajaran, attitude dan persepsi para anak didik.

Menurut Houghey ada tiga kemungkinan dalam penembangan sistem pembelajaran berbasis internet, yaitu:

1) Web course adalah pembelajaran secara penuh berbasis internet tanpa tatap muka. Anak didik dan guru/dosen sepenuhnya terpisah. Seluruh bahan ajar, diskusi dan konsultasi, penugasan, latihan, ujian dan kegiatan pembelajaran lainnya sepenuhnya disampaikan melalui internet.

2) Web Centric Course adalah pembelajaran berbasis internet yang memadukan antara belajar jarah jauh dan tatap muka, sebagian materi disampaikan melalui internet dan sebagian lagi melalui tatap muka. Model ini guru bisa memberikan petunjuk kepada anak didik untuk mempelajari materi pembelajaran melalui web yang telah dibuatnya. Dalam tatap muka guru dan anak didik lebih banyak diskusi tentang temuan materi yang telah dipelajari melalui internet.

3) Web Enhanced Course adalah pembelajaran yang memanfaatkan internet sebagai penunjang peningkatan kualitas pembelajaran yang dilakukan di kelas internet berfungsi memberikan pengayaan dan media komunikasi antara guru dan anak didik sesama mereka anggota kelompok atau dengan nara sumber lain.

Perlu kita ketahui bahwa pengembangan e-learning tidak semata-mata hanya menyajikan materi pembelajaran secara online saja, tapi harus komunikatif dan menarik. Guru mendesain materi pembelajaran seakan-akan anak didik belajar dihadapan gurunya melalui layar komputer yang dihubungkan dengan jaringan internet. Untuk menjadikan pembelajaran dengan model $e$ - 
learning menarik dan minati oleh anak didik ada tiga hal yang harus dipenuhi dalam merancang e-learning merurut Onno W. Purbo yaitu "sederhana, personal, dan cepat".

Sistem yang sederhana akan memudahkan anak didik dalam memamfaatkan teknologi dan menu yang ada, dengan kemudahan pada panel yang disediakan, akan mengurangi pengenalan sistem e-learning itu sendiri, sehingga waktu belajar anak didik dapat diefesienkan untuk proses belajar itu sendiri dan bukan pada belajar menggunakan sistem e-learningnya.

Syarat personal disini guru dapat berinteraksi dengan baik seperti layaknya seorang guru yang berkomunikasi dengan anak didinya di depan kelas. Dengan pendekatan dan interaksi yang lebih personal, anak didik di perhatikan kemajuannya, dan dibantu segala keluhan yang dihadapinya. Hal ini akan membuat anak didik betah dan berlama-lama di depan komputernya.

Layanan yang cepat ditunjang dengan respon yang cepat terhadap keperluan dan kebutuhan anak didik lainnya. Dengn demikian perbaikan pembelajaran dapat dilakukan secepat mungkin oleh guru.

Jadi model pembelajaran e-learning mampu menarik minat belajar anak didik untuk mengikuti setiap langkah pembelajaran dengan sukses merupakan tujuan utama. Ketika instruksi disampaikan pada jarak tertentu diharapkan dapat meningkatkan daya serap dari anak didik atas materi yang diajarkan. Untuk mencapai tujuan dari pembelajaran, maka dalam pengembangan suatu aplikasi e-learning perlu diperhatikan terhadap materi yang di ajarkan atau ditampilkan harus menunjang penyampaian informasi yang benar, tidak hanya mengutamakan sisi keindahan saja, harus memperhatikan dengan seksama teknik pembelajaran yang digunakan, memperhatikan juga teknik evaluasinya dan kemajuan anak didik serta penyimpanan data kemajuan anak didik. Jadi pasca pandemi Covid - 19 model pembelajaran e- learning sangat cocok di gunakan oleh seorang guru atau dosen, sebagai solusi dalam proses pembelajaran di setiap jenjang ( SD, SMP,SMA, PT), yang berada di zona merah, kuning pasca new normal.

\section{d. Project Based Learning}

Model pembelajaran project based learning ini diprakarsai oleh hasil implikasi dari surat edaran Mendikbud nomor 4 tahun 2020, yang tujuan utama untuk memberikan pelatihan kepada anak didik untuk lebih bisa berkalaborasi, gotong royong, dan empati dengan sesama. Menurut Mendikbud, model pembelajaran project based learning ini sangat efektif diterapkan untuk para anak didik dengan membentuk kelompok belajar kecil dalam mengerjakan projek, eksperimen, dan inovasi. Model pembelajaran ini sangat cocok bagi anak didik yang berada pada zona kuning dan hijau pasca new normal.

\section{e. Blended Learning}

Model pembelajaran Blended Learning adalah model yang menggunakan dua pendekatan sekaligus, dengan menggunakan sistem daring sekaligus tatap muka melalui video conference. Meskipun anak didik dan guru melakukan pembelajaran dari jarak jauh, keduanya masih bisa berinteraksi satu sama lain.

Dalam Collins Dictionary secara bahasa istilah Blended Learning terdiri dari dua kata "blended dan learning. Kata blended berarti "campuran, bersama untuk meningkatkan kualitas agar bertambah baik", atau formula suatu penyelarasan kombinasi atau perpaduan. Sedangkan learning secara umum adlah belajar, maka maknanya adalah pola pembelajaran yang mengandung unsu percampuran, atau penggabungan anta satu pola dengan pola lainnya. Elenena 
Mosa (2006) menyampaikan bahwa yang dicampurkan adalah dua unsur utama, yaitu pembelajaran di kelas (Classroom lesson) dengan online learning.

Blended Learning adalah sebuah proses pembelajaran yang memanfaatkan berbagai macam pendekatan, dengan memanfaatkan berbagai macam media dan teknologi, dan mengkombinasikan strategi penyampaian pembelajaran dengan tatatp muka, pembelajaran berbassi computer (ofline), dan computer secara online (internet dan mobile learning). Materi pembelajaran yang disampaikan melalui media ini mempunyai grafik, teks, animasi, simulasi, audio dan video.

Secara khusus dalam pendidikan, blended e-learning memiliki makna sebagai berikut:

1) Blended e-learning merupakan penyampaian informasi, komunikasi, pendidikan, pelatihan-pelatihan tentang materi keguruan baik sibstansi materi pembelajaran maupun ilmu pendidikan secara online.

2) Blended e-learning tidak berarti menggantikan model pembelajaran konvensional di dalam kelas, tetapi memperkuat model pembelajaran melalui pengayaan content dan pengembangan teknologi pendidikan.

3) Blended e-learning menyediakan berbagai perangkat alat yang dapat memperkaya nilai belajar konvensioanal kajian terhadap buku teks, CD-ROM, dan pelatihan berbasisi komputer.

4) Memanfaatkan jasa teknologi eletronik; dimana guru dan anak didik, anak didik dan sesama anak didik, atau guru dengan sesama guru dapat berkomunikasi dengan relatif mudah tanpa dibatasi oleh hal-hal yang protekuler.

5) Memanfatkan keunggulan komputer (digital media dan komputer network).

Selanjudnya menurut Watson (2009:3) ada beberapa bentuk implementasi Blended Learning diantaranya:

1) Online penuh, denga nada pilihan untuk melakukan pembelajaran tatap muka (face to face)

2) Sebagian atau online penuh, dengan dibutuhkan waktu tertentu untuk pembelajaran tatap muka (face to face), baik di kelas atau laboratorium.

3) Sebagian besar atau online penuh, dengan anak didik tetap belajar konvensional dalam kelas atau laboratorium setiap hari.

4) Pembelajaran konvensional di kelas, tapi anak didik dipersyaratkan mengikuti aktifitas online tertentu sebagai pengayaan atau tambahan.

5) Pembelajaran konvensional, dengan melibatkan sumber online, dan aktifitas online yang bukan menjadi syarat bagi anak didik mengikutinya.

Tujuan dari model pembelajaran blended learniang adalah; membantu guru untuk berkembang lebih baik di dalam proses pembelajaran, sesuai dengan gaya belajar dan preferensi atau pilihan dalam belajar; menyediakan peluang yang praktis realistis bagi guru untuk pembelajaran secara mandiri, bermanfaat, dan terus berkambang; peningkatan penjadwalan fleksibelitas bagi guru, dengan menggabungkan aspek terbaik dari tatap muka dan instruksi online. Kelas tatap muka dapat digunakan untuk melibatkan anak didik dalam pengalaman interaktif. Sedangkan kelas online memberiakan guru, sedangkan porsi online memberikan anak didik dengan konten multi media yang kaya akan pengetahuan setiap saat, dan di mana saja selama guru memiliki akses internet. 
Dalam acara Ruang Guru (Artikel Prof.Mc.Ginnis) menyebutkan ada enam hal penting yang harus diperhatikan dalam penyelenggaraan Blended Learning:

1) Penyampaian bahan ajar secara konsisten.

2) Serius dalam penyelenggaraan Blended Learning supaya anak didik menjadi cepat mandiri.

3) Bahan ajar harus selalu mengalami perbaikan (updated).

4) Alokasi bisa dimulai dengan $75 \%$ pembelajaran daring dan $25 \%$ tatap muka.

5) Alokasi $25 \%$ di poin ke 4 bisa digunakan untuk penyelenggaraan remidial.

6) Penyelenggaraan Blended Learning diperlukan kepemimpinan untuk melakukan evaluasi peningkatan khualitas pembelajaran.

Dari uraian diatas dapat kita pahami bahwa pada intinya model pembelajaran Blended Learning adalah pembelajaran dengan menggabungkan dua model pembelajaran yaitu online dan ofline. Bisa juga menggabungkan kelebihan atau keunggulan dari model pembelajaran konvensional dengan e-learning, kita gabungkan muali dari segi penyampaian hingga gaya proses pembelajaran, dijadikan sebuah kombinasi pembelajaran yang tetap menekankan interaksi sosial dengan tidak meninggalkan aspek teknologi. Kemudian ada beberapa manfaat guru dalam menerapkan Blended Learning ; pertama dalam kegiatan pembelajaran jarak jauh bisa meningkatkan hasil pembelajaran; kedua bisa meningkatkan kemudahan dalam proses pembelajaran; ketiga bisa mengurangi biaya proses pembelajaran. Model pembelajaran Blended Learning ini juga sebuah jawaban atau solusinya proses dalam proses pembelajaran pasca pandemi Covid - 19 .

\section{KESIMPULAN}

Kata model itu mengandung makna banyak macamnya, sedangkan pembelajaran adalah terjadinya proses belajar mengajar antara guru dengan anak didik. Pelaksanaannya secara sistematis untuk mencapai tujuan dari pembelajaran. Jadi dengan memilih model pembelajaran memudahkan guru dalam melaksanakan pembelajaran di kelas.

Dengan adanya wabah pandemi Covid - 19 yaitu sejenis penyakit yang menular, menyakit ini bisa menyerang siapa saja, mulai dari bayi,anak-anak, hingga orang dewasa dan lebih banya para lansia. Yang pertamakali ditemukan di Wuhan Cina pada akhir Desember 2019. Virus ini menular sangat cepat dan menyebar hampir semua negara termasuk Indonesia. Pada tanggal 11 Maret 2020 WHO menetapkan wabah ini sebagai pandemi global.

Hal ini membuat ada beberapa negara menetapkan kebijakan untuk lockdown untuk mencegah penyebaran virus corona. Di Indonesia sendiri menetapkan PSBB untuk memutuskan mata rantai penyebaran virus corona. Bahkan pemerintah pusat Provinsi dan Kabupaten / Kota memutuskan penerapan kebijakan untuk meliburkan anak didik, dan mulailah menerapkan model pembelajaran daring, dan kebijakan ini mulai berlaku Senin 16 Maret 2020.

Sistem pembelajaran daring adalah sistem pembelajaran tanpa tatap muka secara langsung antara guru dan anak didik. Sistem ini sesuai dengan edaran nomor 4 Tahun 2020 tentang Pelaksanaan Kebijakan Pendidikan dalam Masa Darurat Penyebaran Corona Virus Disease (COVID- 19). Maka dalam proses pembelajaran daring, perlu untuk adanya pesan-pesan edukatif kepada orang tua dan anak didik tentang wabah pandemi Covid - 19. Dengan demikian pmbelajaran daring sama dengan pembelajaran tatap muka akan tetapi berbasis online. Dampaknya sangat baik, efektif, dan mudah-mudahan programnya tepat sasaran dan tujuan dari pembelajaran akan tercapai. 
Dengan menggunakan beberapa model pembelajaran, yang ditawarkan pasca pandemi Covid- 19, maka banyak sekolah dan perguruan tinggi masih bisa melaksanakan proses pembelajaran. Guru dan anak didik bisa lebih luwes dalam pemanfataan waktu belajar dan mengajar.

\section{DAFTAR PUSTAKA}

Agus Mustakim, (2020). Instruktur Nasional Kurikulum PAI dan Budi Pekerti Kemenag RI dalam Webinar Internasional di STAIN Teungku Dirundeng Meulaboh tanggal 19 Agustus “ Extraordinary Teaching Dalam Pembelajaran Daring”.

Basyirun Usman, (2005). Metodologi Pembelajaran Agama Islam, Cetakan III, Ciputat: Ciputat Press.

Fathurrohman. (2006). Pelatihan Guru Post Traumatik tanggal 21 Agustus 2006 Jurusan Pendidikan Prasekolah dan Sekolah Dasar Fakultas Ilmu Pendidikan Universitas Negeri Yogyakarta.

Istarani, (2010). 58 Model Pembelajaran Innovatif, Medan: Media Persada.

Jihad dan Harris, (2012). Evaluasi pembelajaran, Yogyakarta: Multi Presindo.

Keputusan Bersama Menteri Pendidikan dan Kebudayaan, Menteri Agama, Menteri Kesehatan, dan Menteri Dalam Negeri RI Nomor 01/KB/2020/; Nomor 516 tahun 2020; Nomor HK.03.01/Menkes/363/2020; Nomor 440-882 Tahun 2020 tentang Panduan Penyelenggaraan Panduan Penyelenggaraan Pembelajaran pada Tahun Ajaran 2020/2021 dan Tahun Akademik 2020/2021 di Masa Pandemi Corona Virus Disease 2019 (Covid 19).

Keputusan Bersama Menteri Pendidikan dan Kebudayaan, Menteri Agama, Menteri Kesehatan, dan Menteri Dalam Negeri RI Nomor 03/KB/2020 Nomor 612 Tahun 2020 Nomor HK.01.08/Menkes/502/2020 Nomor 119/4536/SJ Tentang Perubahan atas Keputusan Bersama Menteri Pendidikan dan Kebudayaan, Menteri Agama, Menteri Kesehatan, dan Menteri Dalam Negeri RI Nomor 01/KB/2020, Nomor 516 Tahun 2020., Nomor HK.03.01/Menkes/363/2020, Nomor 440-882 Tahun 2020 Tentang Panduan Penyelenggaraan Pembelajaran pada Tahun Ajaran 2020/2021 dan Tahun Akademik 2020/2021 di Mada Pandemi Corona Virus Disease 2019 (Covid-19).

Miarso.Y, (2005). Menyemai Benih Teknologi Pendidikan. Jakarta: Kencana.

Nurdin. Ichsan, (2020). Blended Learning Dalam Pembelajaran, http://daengicn.blogspot.co.id./2013 /12/Blended Learning-dalam pembelajaran.html. ( Diakses tanggal 15 Oktober 2020).

Prayitno, Wendhie, Implementasi Blended Learning dalam Pembelajaran Pada Pendidikan Dasar dan Menengah'. Htt://Ipmpjogja.org/wp-content/uploads/2015/02/Blended-Learning _Wendhie.pdf. ( Diakses tanggal 14 Oktober 2020).

Profesor Mc.Ginnis, (2020). Building a Successful Blended Learning Strategy, Ruang Guru, 2005, (Diakses 18 Oktober 2020).

Punaji Setyosari, (2007). Belajar Berbasis Masalah (Problem based Learning), Makalah disampaikan dala Pelatihan Dosen-dosen PGSD FIP UNY di Malang. Gardner, J.W. Problem-based learning. (http://www.studygs.net/pbl.htm:media-grafika.com./modelmodel-pembelajaran). 
Rusman, (2014). Seri Manajemen Sekolah Bermutu Model-Model Pembelajaran mengembangkan Profesionalisme Guru, Edisi 2, Cet. 5, Jakarta: Rajawali Pers.

Sastradi, Trisna. (2016). Model Pembelajaran Blended Learning“. http://www.mediafunia.com/2016/07/model-blended-learning.html. (Diakses tanggal 14 Oktober 2020)

Setyosari, P. (2008). Pembelajaran Sistem Online: Tantangan dan Rangsangan. Dosen Jurusan TEP Fakultas Ilmu Pendidikan Universitas Negeri,

Shoimin, (2013). 68 Model Pembelajaran Innovatif dalam Kurikulum 2013, Yogyakarta: ArRuzz Media

Surat Edaran Menteri Agama RI Nomor: B-1673.1/DJ.1/08/2020 Tentang Panduan Penyelenggaran Pembelajaran pada Tahun Ajaran 2020/2021 dan Tahun Akademik 2020/2021 Bagi Satuan Pendidikan Madrasah, Pesantren, Pendidikan Keagamaan Islam, dan Perguruan Tinggi Keagamaan Islam di Masa Pandemi Corona Virus Disease 2019 (Covid-19).

Surat Edaran Nomor 36962/MPK.A/HK/2020 agar seluruh kegiatan belajar mengajar baik di sekolah maupun kampus perguruan tinggi menggunakan metoda daring (dalam jaringan) alias online sebagai upaya pencegahan terhadap perkembangan dan penyebaran Coronavirus disease (Covid-19).

Tian Belawati dan Nizam (Ed), (2020). Potret Pendidikan Tinggi di Masa Covid-19, Jakarta: Direktorat Pendidikan Tinggi, Kementerian Pendidikan dan Kebudayaan.

Wahyudi, (2009). Kepemimpinan Kepala Sekolah Dalam Organisasi Pembelajar (Learning Organization), Cetakan kesatu, Bandung: Alfabeta.

Yazid, Muhammad, (2012). E- Learning Sebagai Media Pembelajaran Interaktif Berbasis Teknologi Informasi, Jurnal Ilmiah Foristek, Vol. 2, No.1. 